\title{
NADPH Oxidase Contributes to Angiotensin II Signaling in the Nucleus Tractus Solitarius
}

\author{
Gang Wang, ${ }^{1}$ Josef Anrather, ${ }^{1}$ Jie Huang, ${ }^{1}$ Robert C. Speth, ${ }^{2}$ Virginia M. Pickel, ${ }^{1}$ and Costantino Iadecola ${ }^{1}$ \\ ${ }^{1}$ Division of Neurobiology, Department of Neurology and Neuroscience, Weill Medical College of Cornell University, New York, New York 10021, and \\ ${ }^{2}$ Department of Pharmacology, University of Mississippi School of Pharmacy, University, Mississippi 38677
}

\begin{abstract}
Angiotensin II (AngII), acting through angiotensin type $1\left(\mathrm{AT}_{1}\right)$ receptors, exerts powerful effects on central autonomic networks regulating cardiovascular homeostasis and fluid balance; however, the mechanisms of AngII signaling in functionally defined central autonomic neurons have not been fully elucidated. In vascular cells, reactive oxygen species (ROS) generated by the enzyme NADPH oxidase play a major role in AngII signaling. Thus, we sought to determine whether NADPH oxidase is present in central autonomic neurons and, if so, whether NADPH oxidase-derived ROS are involved in the effects of AngII on these neurons. The present studies focused on the intermediate dorsomedial nucleus of the solitary tract (dmNTS) because this region receives autonomic afferents via the vagus nerve and is an important site of AngII actions. Using double-label immunoelectron microscopy, we found that the essential NADPH oxidase subunit gp91 ${ }^{\text {phox }}$ is present in somatodendric and axonal profiles containing $\mathrm{AT}_{1}$ receptors. The gp91 $^{\text {phox }}$-labeled dendrites received inputs from large axon terminals resembling vagal afferents. In parallel experiments using patch clamp of dissociated NTS neurons anterogradely labeled via the vagus, we found that AngII potentiates the L-type $\mathrm{Ca}^{2+}$ currents, an effect mediated by $\mathrm{AT}_{1}$ receptors and abolished by the ROS scavenger Mn(III) tetrakis (4-benzoic acid) porphyrin chloride. The NADPH oxidase assembly inhibitor apocynin and the peptide inhibitor gp91 ${ }^{\text {phox }}$ docking sequence, but not its scrambled version, also blocked the potentiation. The results provide evidence that NADPH oxidase-derived ROS are involved in the effects of AngII on $\mathrm{Ca}^{2+}$ influx in NTS neurons receiving vagal afferents and support the notion that ROS are important signaling molecules in central autonomic networks.
\end{abstract}

Key words: nucleus of the solitary tract; angiotensin II; NADPH oxidase; patch clamp; reactive oxygen species; voltage-gated Ca ${ }^{2+}$ channels

\section{Introduction}

A select group of brainstem nuclei, belonging to the central autonomic nervous system, plays a critical role in the maintenance of cardiovascular homeostasis (Reis, 1984; Dampney, 1994). These centers, including the nucleus of solitary tract (NTS), process incoming signals from arterial baroreceptors and cardiopulmonary receptors and coordinate cardiovascular adjustments by regulating cardiac function, vascular resistance, and fluid balance (Aicher et al., 2000; Chapleau and Abboud, 2001). Dysregulation within these centers disrupts cardiovascular homeostasis and leads to pathological conditions such as hypertension and heart failure (Dickinson, 1991).

Angiotensin II (AngII) has emerged as a critical mediator in central autonomic regulation. AngII is produced from sequential enzymatic cleavage of angiotensinogen by renin and angiotensin converting enzyme and exerts its effects by activating G-proteincoupled receptors, mainly angiotensin type $1\left(\mathrm{AT}_{1}\right)$ and type 2 $\left(\mathrm{AT}_{2}\right)$ receptors (Berry et al., 2001). In addition to the "classical"

Received March 30, 2004; revised May 3, 2004; accepted May 4, 2004

This work was supported by National Institutes of Health Grants HL18974 and NS38252. We thank Dr. Teresa A. Milner for her helpful suggestions on this manuscript.

Correspondence should be addressed to Dr. Gang Wang, Division of Neurobiology, Weill Medical College of Cornell University, 411 East 69th Street, New York, NY 10021. E-mail: gaw2001@med.cornell.edu. D0I:10.1523/JNEUROSCI.1176-04.2004

Copyright $\odot 2004$ Society for Neuroscience $\quad$ 0270-6474/04/245516-09\$15.00/0 renin-angiotensin system, which generates circulating AngII, tissue-specific AngII synthesis occurs in many organs, including the brain (Phillips and Sumners, 1998). In brain, AngII is present in autonomic nuclei and has been implicated in central mechanisms leading to hypertension, cardiac dysfunction, and volume dysregulation, effects mediated by brain $\mathrm{AT}_{1}$ receptors (Veerasingham and Raizada, 2003).

Recent evidence suggests that reactive oxygen species (ROS) are involved in signaling by AngII in central autonomic networks (Zimmerman and Davisson, 2004). The main source of AngIIderived ROS in vascular cells is NADPH oxidase (Griendling et al., 1994; Mohazzab et al., 1994), an enzyme first described in phagocytes (Lassègue and Clempus, 2003). NADPH oxidase is composed of two membrane-bound subunits, gp91 ${ }^{\text {phox }}$ and p22 $2^{\text {phox }}$, several cytoplasmic subunits, $\mathrm{p} 47^{\text {phox }}, \mathrm{p} 40^{\text {phox }}$, and p67 ${ }^{\text {phox }}$, and the small G-proteins Rac and Rapla (Kim and Iwao, 2001; Lassègue and Clempus, 2003). After stimulation of $\mathrm{AT}_{1}$ receptors by AngII, the cytoplasmic subunits bind to the membrane subunits and activate the enzyme, resulting in production of superoxide ( $\mathrm{Li}$ and Shah, 2002; Groemping et al., 2003; Taniyama and Griendling, 2003). Although NADPH oxidase subunits gp91 ${ }^{\text {phox }}$ and $\mathrm{p} 47^{\text {phox }}$ have been described in neurons in culture (Noh and Koh, 2000; Tammariello et al., 2000), their presence in central autonomic neurons, their relationships to $\mathrm{AT}_{1}$ receptors, and their roles in AngII signaling have not been established. 
Using ultrastructural and functional approaches, this study sought to determine whether NADPH oxidase-derived ROS are involved in AngII signaling in central autonomic neurons. We focused on the dorsomedial NTS (dmNTS) at the level of the area postrema because this area is the site of termination of cardiovascular vagal afferents and plays a major role in AngII-involved autonomic regulation (Paton and Kasparov, 1999; Boscan et al., 2002; Diz et al., 2002; Lohmeier et al., 2002; DiBona and Jones, 2003). Double-label immunoelectron microscopy demonstrated that gp91 ${ }^{\text {phox }}$ and $\mathrm{AT}_{1}$ receptors are colocalized in the dmNTS neurons. Furthermore, patch-clamp experiments in dissociated NTS neurons receiving vagal afferents (second-order sensory neurons) revealed that ROS generated by NADPH oxidase contribute to AngII-induced $\mathrm{Ca}^{2+}$ influx. These findings provide the structural and functional basis supporting the hypothesis that NADPH oxidase-derived ROS play a major role in central autonomic AngII signaling.

\section{Materials and Methods}

All experiments were performed in compliance with the guidelines of the Institutional Animal Care and Use Committee at Weill Medical College of Cornell University.

\section{Chemicals and peptides}

AngII, nifedipine, BayK 8644 (BayK), $\omega$-conotoxin GVIA (GVIA), $\mathrm{CdCl}_{2}$ $\left(\mathrm{Cd}^{2+}\right)$, Pronase, and thermolysin were purchased from Sigma (St. Louis, MO). Apocynin and $\mathrm{Mn}$ (III) tetrakis (4-benzoic acid) porphyrin chloride (MnTBAP) were purchased from Calbiochem (La Jolla, CA). Losartan was a gift from Merck Pharmaceutical Company. The polypeptide gp91 ${ }^{\text {phox }}$ docking sequence (gp91ds) [H]GGGGCSTRIRRQL[NH ${ }_{2}$ ] (Bio-Synthesis, Lewisville, TX), which prevents NADPH oxidase assembly by blocking the binding of gp91 ${ }^{\text {phox }}$ to $\mathrm{p} 47^{\text {phox }}$, was used to inhibit gp91 ${ }^{\text {phox }}$-containing NADPH oxidase (Rey et al., 2001). The scrambled gp91ds sequence $[\mathrm{H}]$ GGGGCLRITRQSR $\left[\mathrm{NH}_{2}\right.$ ] was used as control peptide. Both gp91ds and scrambled peptide were C-terminally labeled with the fluorochrome tetramethyl rhodamine to document their loading into NTS neurons through recording pipettes.

\section{Antibodies}

For single- and dual-labeling studies of gp $91^{\text {phox }}$, we used goat polyclonal antiserum against gp91 ${ }^{\text {phox }}$ (C-15; Santa Cruz-5827). This antibody has an affinity against a peptide mapping at the $\mathrm{C}$ terminal of gp91 ${ }^{\text {phox }}$ of human origin but also shows full recognition of $\mathrm{gp} 91^{\text {phox }}$ of mouse and rat origin by Western blotting, immunoprecipitation, and immunocytochemistry (Santa Cruz Biotechnology, Santa Cruz, CA). Within the NTS region, previous adsorption of the antiserum with excess C-15 peptide (Santa Cruz Biotechnology) removed all detectable immunoreactivity.

For labeling of $\mathrm{AT}_{1}$ receptors we used a rabbit polyclonal antiserum directed against C-terminal peptide \#92578 amino acids 341-355 (PSDNMSSSAKKPASC) of the rat $\mathrm{AT}_{1 \mathrm{~A}}$ receptor. The antiserum is the same as that used in our previous study of $\mathrm{AT}_{1 \mathrm{~A}}$ receptor distribution (Huang et al., 2003) except that it was not purified for separation of the $\mathrm{AT}_{1 \mathrm{~A}}$ and $\mathrm{AT}_{1 \mathrm{~B}}$ subtypes and thus is designated as an $\mathrm{AT}_{1}$ receptor antiserum. Previous adsorption of the antiserum with the $\mathrm{AT}_{1}$ sequence resulted in loss of immunoreactivity.

\section{Electron microscopy}

As described in detail previously (Huang et al., 2003), adult (180-250 $\mathrm{gm})$, male Sprague Dawley rats (Taconic, Germantown, NY) were anesthetized with sodium pentobarbital (100 mg/kg, i.p.), and their brains were fixed by aortic arch perfusion with (1) $20 \mathrm{ml}$ of heparin (1000 $\mathrm{U} / \mathrm{ml}$ ), (2) $50 \mathrm{ml}$ of $3.8 \%$ acrolein (Polysciences, Warrington, $\mathrm{PA}$ ) in $2 \%$ paraformaldehyde in $0.1 \mathrm{M} \mathrm{PB}, \mathrm{pH} 7.4$, and (3) $200 \mathrm{ml}$ of $2 \%$ paraformaldehyde in $0.1 \mathrm{M}$ PB. The brains were removed and postfixed for $30 \mathrm{~min}$ in $2 \%$ paraformaldehyde in $0.1 \mathrm{M} \mathrm{PB}, \mathrm{pH}$ 7.4. Coronal sections of $40 \mu \mathrm{m}$ were cut through the region of the NTS using a Leica Vibratome (Leica Microsystems, Nussloch, Germany). The sections were next incubated for $15 \mathrm{~min}$ in a cryoprotectant solution containing 25\% sucrose and 3\% glycerol in $0.05 \mathrm{M} \mathrm{PB}$ and rapidly frozen by sequential immersion in liquid chlorodifluoromethane (Freon) (Honeywell, Morristown, NJ) and liquid nitrogen. The frozen sections were thawed by immersion in $0.1 \mathrm{M} P B$ at room temperature, a procedure shown to markedly improved antisera penetration. The thawed sections were incubated for $30 \mathrm{~min}$ in $0.5 \%$ bovine serum albumin (BSA) in $0.1 \mathrm{~m}$ TBS to minimize nonspecific staining.

For single immunoperoxidase labeling of gp $91^{\text {phox }}$, free-floating coronal sections through the intermediate dmNTS at the level of the area postrema were incubated for $48 \mathrm{hr}$ at $4^{\circ} \mathrm{C}$ in the goat gp91 ${ }^{\text {phox }}$ antiserum at a 1:500 dilution in TBS containing $0.1 \%$ BSA. These sections were rinsed and placed for $30 \mathrm{~min}$ in biotinylated donkey anti-goat IgG (1:400; Jackson ImmunoResearch Laboratories, West Grove, PA) and avidinbiotin peroxidase complex (ABC Elite Kit, Vector Laboratories, Burlingame, $\mathrm{CA}$ ). The bound peroxidase was identified by reaction of the sections for 6 min in 3,3' diaminobenzidine (DAB; Sigma) and hydrogen peroxide.

In dual-labeling studies, the rabbit $\mathrm{AT}_{1}$ receptor antiserum (1:500) was detected by using immunoperoxidase labeling (Huang et al., 2003), and the goat anti-gp91 ${ }^{\text {phox }}$ antiserum (1:50) was detected by using immunogold. For this, sections prepared as described above were incubated in a TBS with appropriate dilutions of two antisera for $24 \mathrm{hr}$ at room temperature and for $24 \mathrm{hr}$ at $4^{\circ} \mathrm{C}$. After the primary antisera incubation, the sections of tissue were rinsed and placed for $30 \mathrm{~min}$ each in (1) biotinylated secondary donkey anti-rabbit IgG (1:400; Jackson ImmunoResearch Laboratories) and (2) ABC. These sections were processed using DAB reaction as described above and then rinsed in Tris buffer. For immunogold-labeling of the goat gp91 ${ }^{\text {phox }}$ antiserum, these DABreacted sections were next placed for $2 \mathrm{hr}$ in a 1:50 dilution of donkey anti-goat IgG with bound $1 \mathrm{~nm}$ colloidal gold (Electron Microscopy Sciences, Fort Washington, PA). The gold particles were enlarged for microscopic examination by a $(6-8 \mathrm{~min})$ reaction in a silver solution from the IntenS-EM kit (Amersham Biosciences, Arlington Heights, IL). The sections were postfixed in $2 \%$ osmium tetroxide in $0.1 \mathrm{M} \mathrm{PB}$, dehydrated, and embedded in Epon (EM bed-812) (Electron Microscopy Sciences). Single ultrathin sections containing dmNTS at the level of the area postrema were cut using an ultramicrotome (Nova, Bromma, Sweden). The thin sections were collected onto mesh grids and counterstained with Reynold's lead citrate and uranyl acetate for ultrastructural analysis using a transmission electron microscope (Philips CM-10 or Techni 12 BioTWIN) (FEI, Hillsboro, OR).

\section{Anterograde labeling of NTS neurons receiving vagal afferents}

For electrophysiological studies, second-order visceral sensory neurons in NTS were labeled with a fluorescent marker using previously described methods (Mendelowitz et al., 1992; Balkowiec et al., 2000). Briefly, postnatal $(\mathrm{P})$ day $7-14$ rats were anesthetized by a mixture of $8 \mathrm{mg} / \mathrm{kg}$ ketamine and $8 \mathrm{mg} / \mathrm{kg}$ xylazine. The left vagal nerve was exposed in the neck by a ventral midline excision and isolated from the surrounding tissues with stretched Parafilm "M" (Fisher Scientific, Houston, TX). A few crystals of the anterograde tracer 4-(4-(didecylamino)styryl)- $N$-methylpyridinium iodide (DiA) (Molecular Probes, Eugene, OR) were placed on the nerve at the level of the carotid bifurcation and caudal to the nodose ganglion. To prevent dye leakage, the region was isolated with a fast-hardening silicone elastomer (Kwik-Sil) (World Precision Instruments, Sarasota, FL). The skin was then sutured, and the animals were allowed to recover for 7-10 d. This survival period allowed DiA to penetrate into the nerve bundle and to be anterogradely transported along vagal sensory afferents terminating on NTS neurons.

\section{Patch-clamp recordings}

Dissociation of NTS neurons. Rats (P14-24) were killed using $\mathrm{CO}_{2}$. The brainstem was removed and transferred to a chamber containing ice-cold sucrose-artificial cerebrospinal fluid (aCSF) composed of (in mM): 26 $\mathrm{NaHCO}_{3}, 1 \mathrm{NaH}_{2} \mathrm{PO}_{4}, 3 \mathrm{KCl}, 5 \mathrm{MgSO}_{4}, 0.5 \mathrm{CaCl}_{2}, 10$ glucose, and 248 sucrose, oxygenated with $95 \% \mathrm{O}_{2}$ and $5 \% \mathrm{CO}_{2}, \mathrm{pH}$ 7.4. Coronal slices (400 $\mu \mathrm{m}$ in thickness) were then obtained using a Vibratome and stored in a chamber filled with oxygenated lactic acid (1)-aCSF composed of (in mm): $124 \mathrm{NaCl}, 26 \mathrm{NaHCO}_{3}, 5 \mathrm{KCl}, 1 \mathrm{NaH}_{2} \mathrm{PO}_{4}, 2 \mathrm{MgSO}_{4}, 2 \mathrm{CaCl}_{2}, 10$ glucose, 4.5 lactic acid, $\mathrm{pH}$ 7.3. After $1 \mathrm{hr}$ recovery, the slices were incu- 
bated at $35^{\circ} \mathrm{C}$ with $0.02 \%$ Pronase for $1 \mathrm{hr}$ and then $0.02 \%$ thermolysin for $1 \mathrm{hr}$ in the oxygenated (1)-aCSF (Ishibashi and Akaike, 1995). To dissociate NTS neurons, the region of dmNTS at the level of area postrema was identified using an E600 fluorescence microscope (Nikon, Tokyo, Japan), micropunched, and stirred in the (1)-aCSF with a firepolished Pasture pipette. After dissociation, DiA-labeled presynaptic boutons from the first-order neuron, still attached to second-order NTS neuron membranes, were identified by fluorescence microscopy with a brief exposure to ultraviolet light (Balkowiec et al., 2000). In rats without DiA labeling, the dmNTS neurons were identified on the basis of the morphological criteria characteristic of second-order relay neurons, i.e., small round or oval bipolar cells, with long thin processes (Ishibashi and Akaike, 1995; Balkowiec et al., 2000).

Recordings. The isolated neurons were perfused continuously with oxygenated (1)-aCSF at room temperature $\left(23-25^{\circ} \mathrm{C}\right)$. The whole-cell patch-clamp recording (Hamill et al., 1981) of the NTS neurons was performed $\sim 20 \mathrm{~min}$ after the dissociation. An Axopatch-200A patchclamp amplifier (Axon Instruments, Union City, CA) was used with a glass electrode double pulled with a P-97 micropipette puller (Sutter Instruments, Novato, CA) and fire polished with a microforge (Narishige Scientific Instruments, Tokyo, Japan) to a final resistance of 3-5 M 2 . The pipette solution contained (in $\mathrm{mm}$ ): 145 Cs-gluconate, $17 \mathrm{CsCl}, 5$ EGTA, $1 \mathrm{MgCl}_{2}, 10$ HEPES, 2 ATP, and 0.2 cAMP, pH 7.3. Using $2 \mathrm{~mm}$ $\mathrm{Ca}^{2+}$ as a charge carrier, the voltage-gated $\mathrm{Ca}^{2+}$ channel currents were elicited by depolarization from the holding potential of $-60 \mathrm{mV}$, which is close to resting potentials of NTS neurons (Deuchars et al., 2000), to stepping potentials ranging from -50 to $+20 \mathrm{mV}$. The current signals were filtered at $2 \mathrm{kHz}$, digitized on-line at a sampling rate of $10 \mathrm{kHz}$, and stored for later computer analysis using pClamp version Window 8 software (Axon Instruments). To prevent rundown of the $\mathrm{Ca}^{2+}$ current, ATP and cAMP were included in the pipette solution (for review, see Yamaoka and Kameyama, 2003). A stable $\mathrm{Ca}^{2+}$ current without any significant rundown allowed us to perform pharmacological investigations on each single neuron for $>10 \mathrm{~min}$.

Drug application. AngII, losartan, MnTBAP, apocynin, BayK, nifedipine, GVIA, or $\mathrm{Cd}^{2+}$ was applied to the patched neurons using a selfdesigned, double-barreled, drug-perfusing device. The gp91ds or scrambled peptides were added to the electrode pipette solution.

\section{Data analysis}

Ultrastructure. Ultrastructural analysis of the dmNTS at the level of area postrema was performed on ultrathin sections from at least two Vibratome sections from each of three rats [on the basis of coordinates indicated in the rat brain atlas of Paxinos and Watson (1998)]. The sections used for analysis showed labeling for either gp91 ${ }^{\text {phox }}$ subunits (single) or gp91 ${ }^{\text {phox }}$ subunits plus $\mathrm{AT}_{1}$ receptors (dual) labeling. Immunogold-labeled structures were identified as those containing two or more gold particles. Immunoperoxidase labeling was regarded as positive when the electron-dense precipitate in individual profiles was greater than that seen in other morphologically similar profiles in the neuropil. Neural and glial processes were identified according to the nomenclature of Peters et al. (1991) and defined in the dmNTS region (Huang et al., 2003). Illustrations were prepared by importing digital images from electron microscopy directly into Microsoft Powerpoint using software of this program to enhance contrast, prepare composite plates, and add lettering.

Voltage-gated $\mathrm{Ca}^{2+}$ currents. All electrophysiological data were acquired and analyzed using Window pClamp 8 (Axon Instruments), SigmaPlot 8 (Systat Software, Point Richmond, CA), and Prism 4 (GraphPad Software, San Diego, CA). The $\mathrm{Ca}^{2+}$ current amplitudes were expressed as mean \pm SEM with $n$ as the number of neurons tested. The amplitude of $\mathrm{Ca}^{2+}$ currents at the end of the 500 msec pulse was measured as that of the L-type $\mathrm{Ca}^{2+}$ current, whereas the amplitude of the transient, fast-inactivating $\mathrm{Ca}^{2+}$ current was obtained by subtracting the amplitude of L-type $\mathrm{Ca}^{2+}$ currents from that of peak transient $\mathrm{Ca}^{2+}$ currents measured at $30 \mathrm{msec}$ after initiation of depolarization pulses (Wang et al., 2002a,b). An $\mathrm{EC}_{50}$ (the concentration producing $50 \%$ of maximal effect) and Hill slope coefficient were obtained from the equation $r=$ $100 /\left\{1+10^{\left[(\operatorname{LogEC} 50-\mathrm{C})^{\star} \text { Hillslope }\right]}\right\}$, where $r$ is the percentage of normalized maximal L-type $\mathrm{Ca}^{2+}$ current response at a given AngII concentration C. The statistical significance between two groups was analyzed by the Student's $t$ test. $p$ values $<0.05$ were considered significant.

\section{Results}

\section{Somatodendric gp91 ${ }^{\text {phox }}$ distribution and coexpression with $\mathrm{AT}_{1}$ receptors}

Somatodendric profiles in the dmNTS often contained immunoperoxidase labeling for gp $91^{\text {phox }}$. In somata, the peroxidase reaction product for gp $91^{\text {phox }}$ was seen in aggregates near the plasma membrane, mitochondria, or Golgi lamellae (Fig. 1A). The gp91 ${ }^{\text {phox }}$ immunoreactivity also was associated with organelles resembling smooth endoplasmic reticulum in the region between the plasmalemma and nearby mitochondria (Fig. 1B). A similar but less abundant cytoplasmic distribution of gp $91^{\text {phox }}$ immunoreactivity was seen in somata using the immunogold detection method (Fig. 1C). In dendrites, gp91 ${ }^{\text {phox }}$ immunoreactivity was localized to perisynaptic portions of the plasma membrane and also associated with membranes of smooth endoplasmic reticulum and multivesicular bodies (Fig. $2 A$ ). The gp91 ${ }^{\text {phox }}$ labeling also was diffusely distributed within the dendritic cytoplasm and particularly abundant near mitochondria (Fig. 2B). Axon terminals presynaptic to gp91 ${ }^{\text {phox }}$-labeled dendrites often formed asymmetric excitatory synapses (Fig. $2 A$ ). Many of the large terminals formed multiple dendritic contacts (Fig. $2 B$ ) that are typical of glutamatergic visceral vagal afferents (Aicher et al., 2000).

The $\mathrm{AT}_{1}$ receptor was located in many of the somatodendric profiles containing gp91 ${ }^{\text {phox }}$ (Figs. $1 C, 2 B$ ). Within these profiles, the $\mathrm{AT}_{1}$ receptor labeling was located mainly on nonsynaptic portions of the plasmalemma and within the cytoplasm, often near mitochondria and gp $91^{\text {phox }}$ immunoreactivity. The cellular and subcellular distribution of these receptors using the $\mathrm{AT}_{1}$ receptor antiserum were similar to those described previously for the $\mathrm{AT}_{1 \mathrm{a}}$ receptor antiserum (Huang et al., 2003).

In an area of $6118 \mu \mathrm{m}^{2}$ of tissue examined in the dmNTS of three rats, $40 \%$ of the total 562 somatodendric profiles examined contained gp91 $91^{\text {phox }}$ or $\mathrm{AT}_{1}$ receptor labeling, or both, and the remainder were without detectable immunoreactivity. Of those labeled profiles, 31\% expressed gp91 ${ }^{\text {phox }}, 40 \%$ expressed $\mathrm{AT}_{1}$ receptor, and $29 \%$ expressed both antigens. The immunogold and immunoperoxidase markers were sparsely distributed in the cytoplasm, suggesting that at least some of the apparently unlabeled profiles contained gp91 ${ }^{\text {phox }}$ or $\mathrm{AT}_{1}$ receptor antigens, or both, and that many of those considered as singly labeled may have contained both markers in other planes of section.

\section{Axonal gp91 ${ }^{\text {phox }}$ distribution and association with $\mathrm{AT}_{1}$ receptors}

Numerous small axons and axon terminals contained gp91 ${ }^{\text {phox }}$ or $\mathrm{AT}_{1}$ receptor labeling, or both. In terminals, patches of gp91 ${ }^{\text {phox }}$ immunoreactivity were seen on segments of plasmalemma and around membranes of nearby small clear vesicles (Fig. 2D). In favorable planes of section, both the presynaptic terminals and their postsynaptic dendrites were immunolabeled for gp91 ${ }^{\text {phox }}$ (Fig. 2D). The immunolabeled portions of the plasma membranes were usually apposed to glial processes. Morphologically similar terminals also were dually labeled for gp91 ${ }^{\text {phox }}$ and $\mathrm{AT}_{1}$ receptors (Fig. 2C).

\section{Characterization of voltage-gated $\mathrm{Ca}^{2+}$ currents in second- order NTS neurons}

The conventional whole-cell patch clamp was used to record voltage-gated $\mathrm{Ca}^{2+}$ currents $\left(I_{\mathrm{Ca}}\right)$ in DiA-labeled or morpholog- 

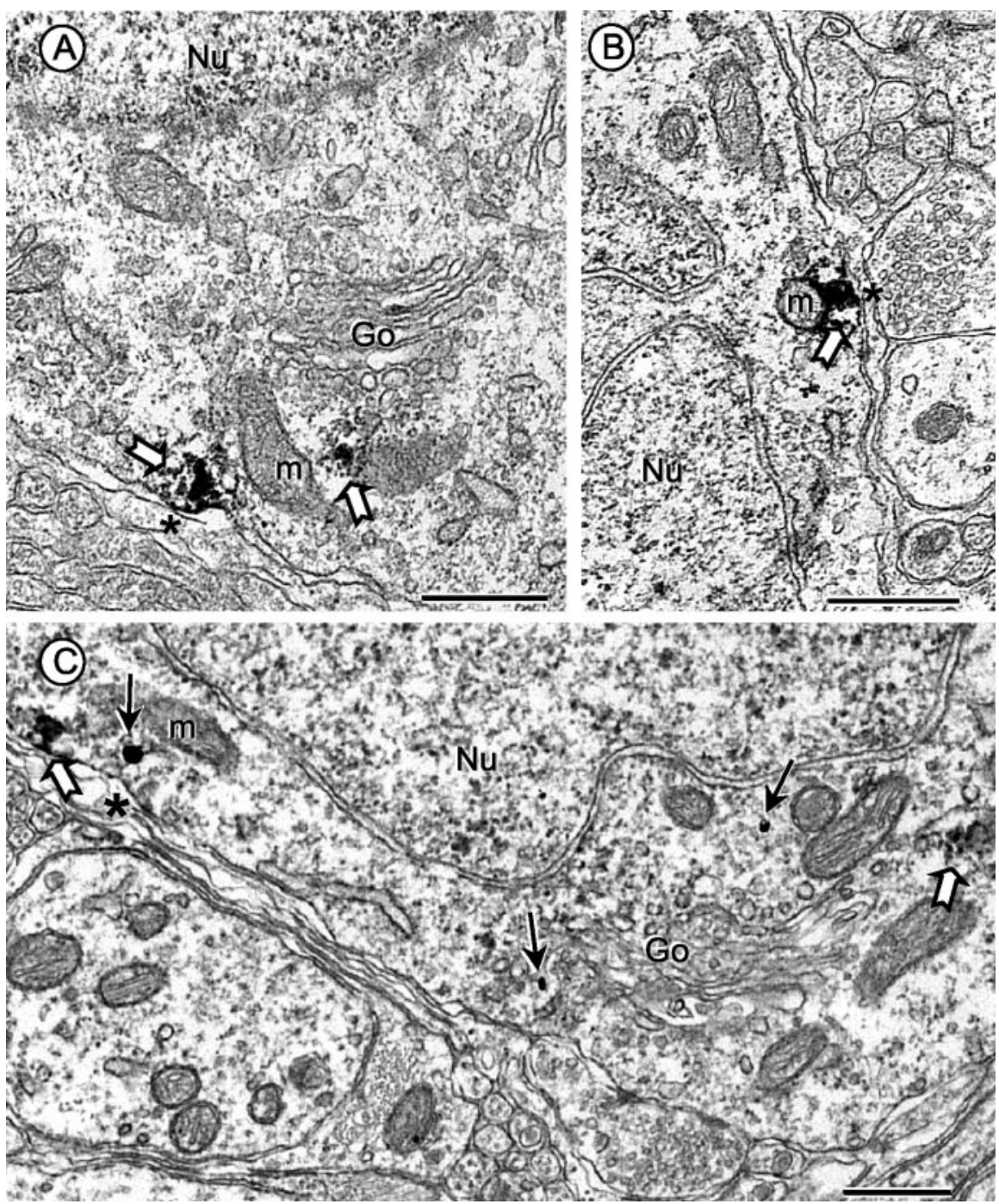

Figure 1. Electron micrographs showing gp $91^{\text {phox }}$ subcellular distribution and coexpression with $\mathrm{AT}_{1}$ receptors in neuronal perikarya in the dorsomedial NTS. $A, B$, In tissue processed only for immunoperoxidase labeling of $\mathrm{gp} 91^{\text {phox }}$, the reaction product (block arrows) is seen within and near the plasma membrane and also near mitochondria ( $\mathrm{m}$ ) and Golgi lamellae (Go) in somatic profiles. C, In dually labeled tissue, the gp91 ${ }^{\text {phox }}$ immunogold (small arrows) has a comparable plasmalemmal and cytoplasmic distribution in a perikaryon that also contains immunoperoxidase identifying the $\mathrm{AT}_{1}$ receptor (block arrows). The nuclei (Nu) in $A-C$ are without immunolabeling for either marker. Scale bars, $0.5 \mu \mathrm{m}$.

ically characterized second-order sensory neurons within the dmNTS (Fig. 3A). The $I_{\mathrm{Ca}}$ is composed of a transient, fastinactivating and a slowly inactivating component, both of which were inhibited by application of $\mathrm{Cd}^{2+}(1 \mathrm{~mm})$, a nonspecific $\mathrm{Ca}^{2+}$ channel blocker (Fig. 3C). Although the transient $I_{\mathrm{Ca}}$ component was partially inhibited by the N-type $\mathrm{Ca}^{2+}$ channel blocker GVIA ( $400 \mathrm{~nm}$ ) (Fig. $3 B$ ), the slow-inactivating $I_{\mathrm{Ca}} \mathrm{com}$ ponent was potentiated by the L-type $\mathrm{Ca}^{2+}$ channel activator BayK $(2 \mu \mathrm{M})$ (Fig. 3B,C) or inhibited by the L-type $\mathrm{Ca}^{2+}$ channel blocker nifedipine $(1 \mu \mathrm{M})$ (Fig. $3 C$ ). These results indicate that although the transient $I_{\mathrm{Ca}}$ component is partially contributed by an N-type $I_{\mathrm{Ca}}$, the slowly inactivating component is dominated by an L-type $I_{\mathrm{Ca}}$ (Nowycky et al., 1985; Fox et al., 1987; Tsien et al., 1988; Ishibashi and Akaike, 1995).

\section{AngII upregulates L-type $\mathrm{Ca}^{2+}$ currents in second-order NTS neurons}

In these experiments we examined the effect of AngII on $\mathrm{Ca}^{2+}$ currents in NTS neurons. Of a total of 24 NTS neurons examined, AngII
(2 $\mu \mathrm{M})$ increased the amplitude of L-type $\mathrm{Ca}^{2+}$ current in 19 neurons (by $47 \pm 11 \%$; $p<0.05)$ (Fig. $4 A)$. AngII $(2 \mu \mathrm{M})$ had no significant effect on the $\mathrm{Ca}^{2+}$ currents of the remaining five (two labeled and three unlabeled) neurons ( $p>0.05)$. The onset of the potentiating effect on $\mathrm{Ca}^{2+}$ currents was seen $\sim 1$ min after the start of local perfusion of AngII $(2 \mu \mathrm{M})$ and lasted as long as AngII was present (up to $5 \mathrm{~min}$ ) (data not shown); however, AngII $(2 \mu \mathrm{M})$ failed to affect the transient $\mathrm{Ca}^{2+}$ current $(p>0.05)$ (Fig. $4 A, B)$. No differences in the effect of AngII $(2 \mu \mathrm{M})$ on the amplitude of L-type $\mathrm{Ca}^{2+}$ currents were observed between DiA-labeled NTS neurons (by $49 \pm 12 \% ; n=11 ; p<$ 0.05 ) and second-order NTS neurons identified by the morphological criteria (by $43 \pm$ $8 \% ; n=8 ; p<0.05)$. Thus, DiA-labeled and morphologically identified second-order NTS neurons possess identical $\mathrm{Ca}^{2+}$ current response to AngII. The potentiating effect of AngII on L-type $\mathrm{Ca}^{2+}$ currents was dose dependent, giving an $\mathrm{EC}_{50}=37.4 \mathrm{~nm}$ and Hill slope coefficient $=1.45$ (Fig. 4C). The current-voltage curve in Figure $4 D$ shows the $I-V$ relation of the L-type $I_{\mathrm{Ca}}$, with activation threshold at $-40 \mathrm{mV}$ and a peak value at $-10 \mathrm{mV}$. Figure $4 D$ also illustrates that AngII (100 nM) potentiates this high-thresholdactivated L-type $I_{\mathrm{Ca}}$ only at negative stepping potentials, especially at -20 and -10 $\mathrm{mV}$, indicating that the potentiating effect of AngII is dependent on negative voltage steps. Collectively, these findings indicate that AngII selectively upregulates the highthreshold voltage-activated L-type $\mathrm{Ca}^{2+}$ current.

\section{$\mathrm{AT}_{1}$ receptors mediate the AngII- induced potentiation of L-type $\mathrm{Ca}^{2+}$ currents}

To determine whether the AngII-induced potentiation of $\mathrm{Ca}^{2+}$ currents is mediated by $\mathrm{AT}_{1}$ receptors, the $\mathrm{AT}_{1}$ receptor antagonist losartan was used. AngII $(2 \mu \mathrm{M})$ failed to increase $\mathrm{Ca}^{2+}$ currents in the co-presence of losartan $(2 \mu \mathrm{M})$ in the perfusion buffer (Fig. $5 A, B)$; however, losartan did not significantly affect the amplitude of the transient $I_{\mathrm{Ca}}$ component (AngII: $87 \pm 5 \%$ of control; AngII plus losartan: $95 \pm 6 \% ; n=4$ per group; $p>0.05$ ). Thus, AngII potentiates the L-type $\mathrm{Ca}^{2+}$ current via $\mathrm{AT}_{1}$ receptors in second-order sensory neurons.

\section{ROS are involved in AngII-mediated potentiation of $\mathrm{Ca}^{2+}$ currents}

To determine whether ROS are involved in the AngII-mediated potentiation of the $\mathrm{Ca}^{2+}$ current, the cell-permeant ROS scavenger MnTBAP (Batinic-Haberle et al., 1998) was used. Application of MnTBAP $(30 \mu \mathrm{M})$ in the perfusion buffer reversed the effect of AngII on the L-type $\mathrm{Ca}^{2+}$ current $(n=4 ; p<0.05)$ (Fig. $5 C, D$ ) without significantly influencing the transient $\mathrm{Ca}^{2+}$ current component (AngII: $97 \pm 5 \%$ of control; AngII plus MnTBAP: $80 \pm 9 \% ; n=4$ per group; $p>0.05)$. 


\section{NADPH oxidase is the source of the ROS}

To determine whether NADPH oxidasegenerated ROS are involved in the AngIImediated potentiation of $\mathrm{Ca}^{2+}$ currents, we examined the effects of NADPH oxidase inhibitors. First, we examined apocynin, an inhibitor of NADPH oxidase assembly (Suzuki et al., 1992). Apocynin (1 $\mathrm{mM}$ ) in the perfusion buffer prevented the potentiation of the L-type $\mathrm{Ca}^{2+}$ current evoked by AngII $(2 \mu \mathrm{M})(n=4 ; p<0.05)$ (Fig. $5 E, F$ ) but did not affect the transient $\mathrm{Ca}^{2+}$ component of the current (AngII: $102 \pm 13 \%$ of control; AngII plus apocynin: $124 \pm 17 \% ; n=4$ per group; $p>$ $0.05)$. We next examined the effect of the NADPH oxidase peptide inhibitor gp91ds (Rey et al., 2001) applied in the pipette solution. The gp91ds $(1 \mu \mathrm{M})$ peptide prevented the augmentation of the $\mathrm{Ca}^{2+}$ current induced by AngII $(2 \mu \mathrm{M})(n=5 ; p>0.05)$ but did not block the effect of the L-type $\mathrm{Ca}^{2+}$ channel activator BayK $(2 \mu \mathrm{M})$ in the perfusion buffer $(n=4 ; p<0.05)$ (Fig. $6 A, B)$. Treatment with the scrambled peptide (1 $\mu \mathrm{M})$ did not prevent the AngII-induced potentiation of the $\mathrm{Ca}^{2+}$ current $(n=4 ; p<$ 0.05) (Fig. 6C,D).

\section{Discussion}

The present study provides new findings supporting a role for NADPH oxidasederived ROS in AngII signaling in the dmNTS. First, we demonstrated by electron microscopy that the essential NADPH oxidase subunit gp91 $1^{\text {phox }}$ was present in both somatodendric and axonal profiles, many of which contain $\mathrm{AT}_{1}$ receptors, in the dmNTS. The afferents to the gp9 $91^{\text {phox }}$-containing somata and dendrites, as well as many of the single or dually labeled axon terminals, had ultrastructural features of vagal afferents. Second, in the dissociated second-order NTS neurons, the AngII-elicited potentiation of the L-type $\mathrm{Ca}^{2+}$ current was reversed by ROS scavenger MnTBAP, indicating that ROS, probably superoxide (Patel and Day, 1999), are involved in the action of AngII on $\mathrm{Ca}^{2+}$ currents. Finally, the AngII-induced potentiation of $\mathrm{Ca}^{2+}$ currents was also blocked by inhibition of NADPH oxidase using both pharmacological (apocynin) and nonpharmacological (gp91ds) approaches. Collectively, all of these findings provide evidence that ROS produced by NADPH oxidase plays a major role in the AngII-dependent potentiation of $\mathrm{Ca}^{2+}$ currents, an effect that may contribute to the powerful actions of AngII on the excitability of central autonomic neurons (Kasparov and Paton, 1999; Ferguson et al., 2001).

\section{Methodological considerations}

The localization of $\mathrm{AT}_{1}$ receptors in the dmNTS is comparable with that described in a previous study using the same antiserum that had been passed over an affinity column to derive an $\mathrm{AT}_{1 \mathrm{~A}}$ selective component (Huang et al., 2003). The use of each anti-
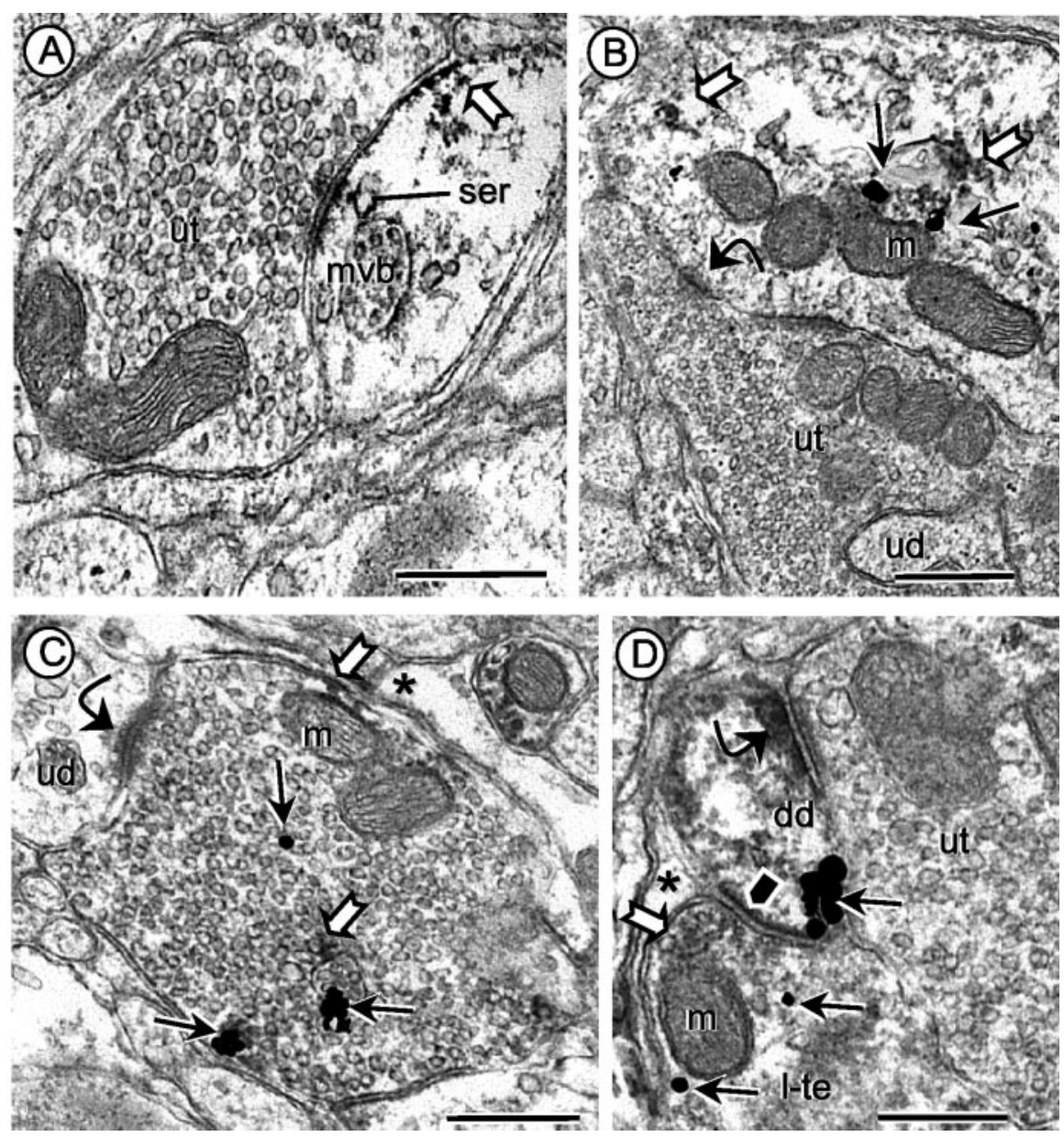

Figure 2. Dendritic and axonal distribution of gp9 $1^{\text {phox }}$ and $\mathrm{AT}_{1}$ receptors in dmNTS. $A$, Immunoperoxidase labeling for gp $91^{\text {phox }}$ is seen along perisynaptic portions of the plasma membrane and near membranes of smooth endoplasmic reticulum (ser) and a multivesicular body (mvb) in a dendrite receiving input from an unlabeled axon terminal (ut). $B$, In dual-labeled tissue, mmunogold gp91 ${ }^{\text {phox }}$ (thin arrows) and immunoperoxidase (block arrows) labeling for the $\mathrm{AT}_{1}$ receptor are seen within the terminal is large and also contacts a small, unlabeled dendritic profile (ud). C, Immunogold labeling (small arrows) for gp $91^{\text {phox }}$ s. (small arrows) labeling for gp91 ${ }^{\text {phox }}$ receives an excitatory synapse (curved arrow) from an unlabeled (istight and diffusely distributed (white block arrow) around a large dense-core vesicle and a mitochondrion $(\mathrm{m})$ near the presynaptic membrane specialization. Astrocytic processes (asterisk) are identified in ( and D, and one mitochondrion ( $\mathrm{m}$ ) is indicated near the immunolabeled plasma membrane in C. Scale bars, $0.5 \mu \mathrm{m}$.

serum at optimal high dilutions significantly reduced background labeling, enabling identification of relatively low levels and heterogeneously dispersed aggregates of immunoreactivity within the cytoplasm. The immunogold labeling method, however, is considerably less sensitive than the avidin-biotin-peroxidase method (Leranth and Pickel, 1989). The differences in sensitivity, together with the heterogeneous cytoplasmic and plasmalemmal distribution of both $\mathrm{AT}_{1}$ receptor and gp $91^{\text {phox }}$, may have resulted in an underestimation of the number of profiles that were single or dually labeled.

The patch-clamp analysis shows that L-type $\mathrm{Ca}^{2+}$ currents in DiA-labeled and morphologically characterized second-order dmNTS neurons share similar responsiveness to AngII. Therefore, our results cannot be attributed to heterogeneity of the neuronal population examined. The effect of gp91ds is unlikely to result from actions unrelated to NADPH oxidase inhibition, 
A

\section{Bright Field}

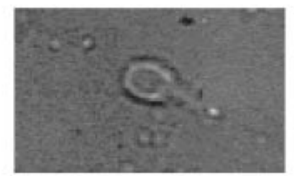

B
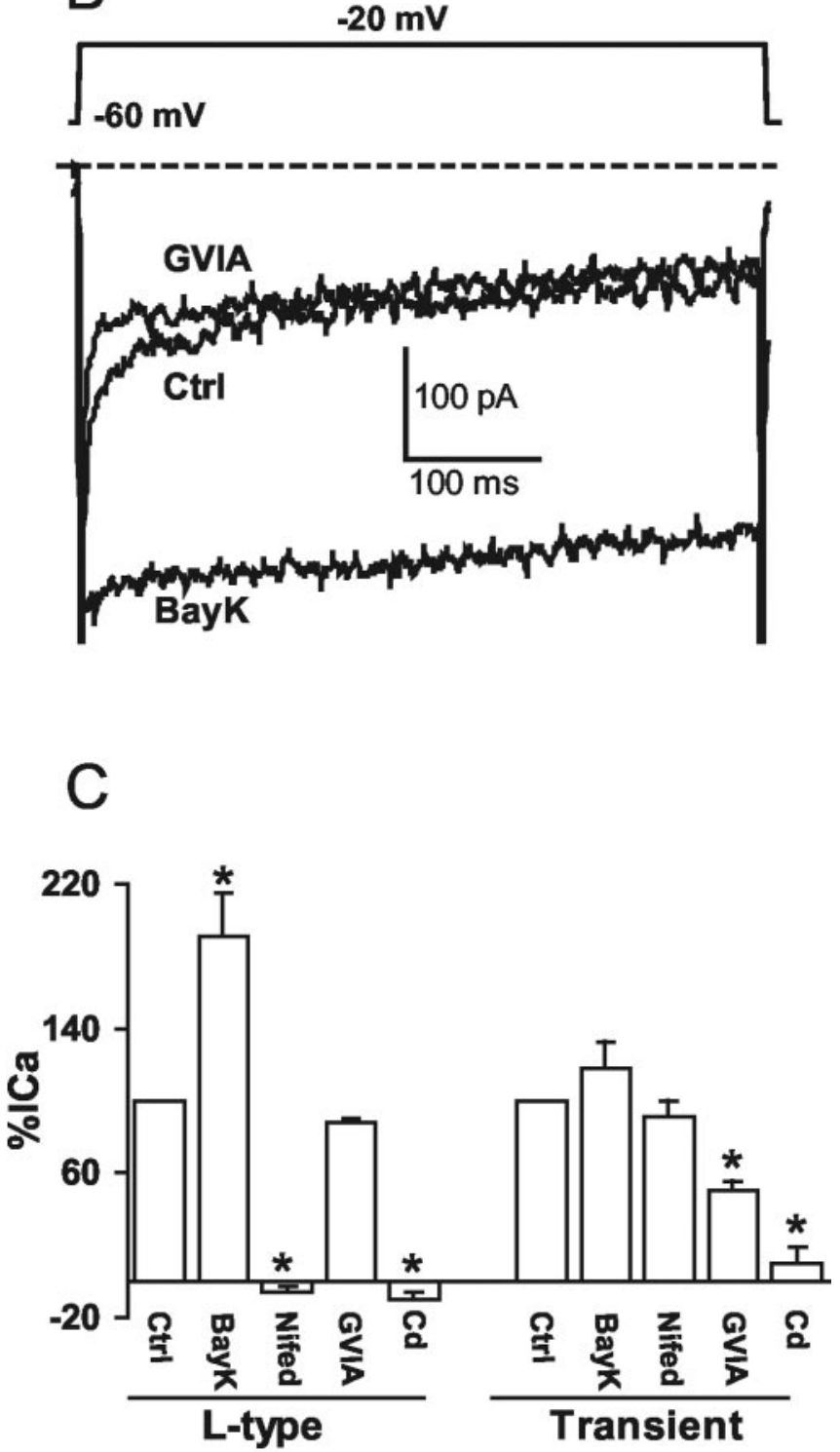

Figure 3. Properties of voltage-gated $\mathrm{Ca}^{2+}$ currents in second-order sensory NTS neurons. $A, A$ isolated labeled NTS neuron was seen in bright field (left) or fluorescence (right). Scale bar, $20 \mu \mathrm{m}$. B, Representative traces of whole-cell, voltage-gated $\mathrm{Ca}^{2+}$ channel currents elicited from the holding potential (HP) of $-60 \mathrm{mV}$ to the stepping potential (SP) of $-20 \mathrm{mV}$ in a labeled NTS neuron. The L-type $\mathrm{Ca}^{2+}$ channel activator BayK $(2 \mu \mathrm{m})$ was applied after the $\mathrm{N}$-type $\mathrm{Ca}^{2+}$ channel blocker GVIA (400 nm) inhibited the transient $\mathrm{Ca}^{2+}$ current. The dashed line indicates zero level of the current. C, Percentage of changes in the amplitude of the L-type and transient $\mathrm{Ca}^{2+}$ currents, respectively, are shown in control (Ctrl) conditions and in the presence of BayK (2 $\mu \mathrm{M})(n=5)$, nifedipine (nifed) (1 $\mu \mathrm{M})(n=4), \mathrm{GVIA}(400 \mathrm{nM})(n=3)$, or $\left(\mathrm{d}^{2+}(1 \mathrm{~mm})(n=3) .{ }^{*} p<0.05\right.$.
A

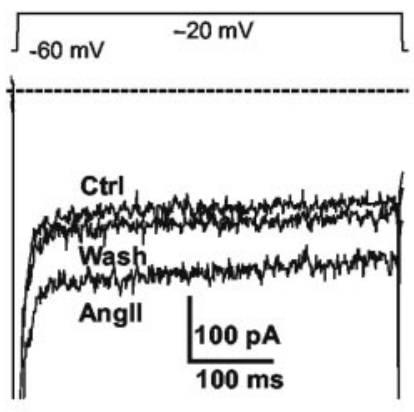

B

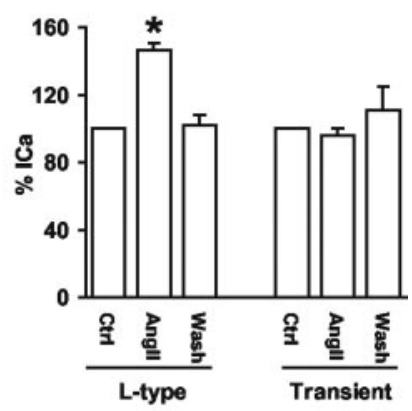

C
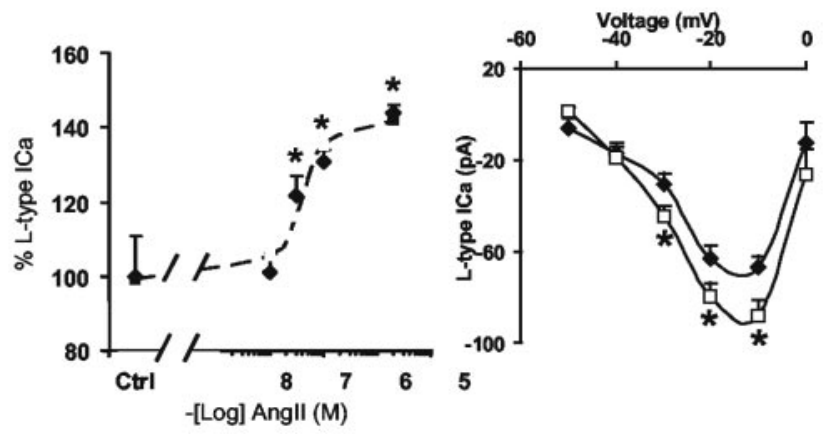

Figure 4. Angll potentiates L-type $\mathrm{Ca}^{2+}$ currents in second-order sensory NTS neurons. $A$, Representative traces of the whole-cell $\mathrm{Ca}^{2+}$ current in control conditions, with Angll $(2 \mu \mathrm{M})$, or after wash with the control buffer. The dashed line indicates zero level of the current. HP = $-60 \mathrm{mV} ; \mathrm{SP}=-20 \mathrm{mV} . B$, Percentage of changes in amplitudes of the L-type and transient $\mathrm{Ca}^{2+}$ currents in control (Ctrl) conditions, with Angll $(2 \mu \mathrm{m})(n=8)$, or after wash with the control buffer $(n=4)$. C, The concentration-response curve of the Angll-mediated effect on L-type $\mathrm{Ca}^{2+}$ currents. The $\mathrm{EC}_{50}$ was $37.4 \mathrm{~nm}$, and the Hill slope coefficient was 1.45. The dashed line is the fitted curve. D, The $\mathrm{I}-V$ curve of $\mathrm{L}$-type $\mathrm{Ca}^{2+}$ currents in control ( ) conditions shows that this current is high-voltage threshold activated $(n=4)$. In the presence of Angll $(100 \mathrm{~nm})(\square)$, the amplitude of the L-type $\mathrm{Ca}^{2+}$ current increased only at a range of negative stepping potentials, especially at -10 and $-20 \mathrm{mV}(n=4) .{ }^{*} p<0.05$.

because the scrambled peptide did not affect AngII-induced potentiation of $\mathrm{Ca}^{2+}$ currents. Furthermore, the effect of apocynin on the potentiation of $\mathrm{Ca}^{2+}$ currents was identical to that of the peptide inhibitor gp91ds. Finally, the effect of gp91ds is unlikely to result from nonspecific block of $\mathrm{Ca}^{2+}$ channels, because the peptide did not prevent BayK 8644 from activating the L-type $\mathrm{Ca}^{2+}$ channel current.

Presence of gp91 ${ }^{\text {phox }}$ in NTS neurons that also contain $\mathrm{AT}_{1}$ receptors

Within somata and dendrites, the gp $91^{\text {phox }}$ immunoreactivity was associated with cytoplasmic organelles and was also seen at synaptic and extrasynaptic portions of the plasma membrane. The association with organelles resembling smooth endoplasmic reticulum is consistent with the role of these structures in the intracellular trafficking of surface proteins (Ehlers, 2000). Many of the somatodendric profiles containing gp $91^{\text {phox }}$ also coexpress $\mathrm{AT}_{1}$ receptors. The colocalization of $\mathrm{AT}_{1}$ receptors and gp91 9 phox provides the ultrastructural basis for the functional interaction between AngII and NADPH oxidase demonstrated by patchclamp studies; however, because gp91 ${ }^{\text {phox }}$ exists in several isoforms (nox 1 through 4) (Cai et al., 2003), we cannot exclude the possibility that $\mathrm{AT}_{1}$ receptors are associated with NADPH oxi- 
A

B
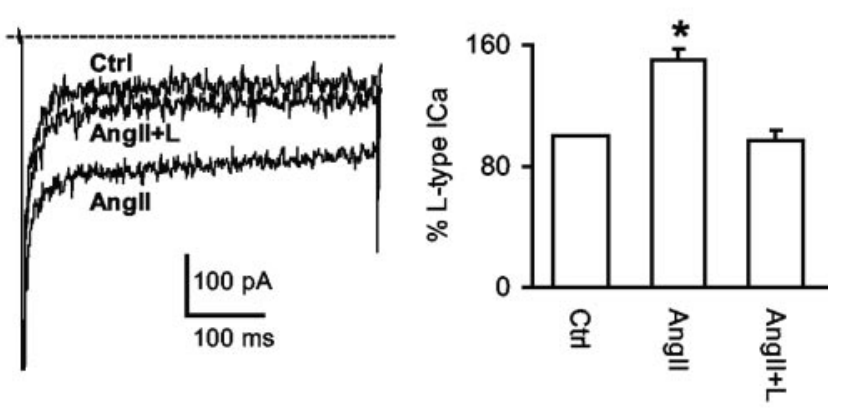

C
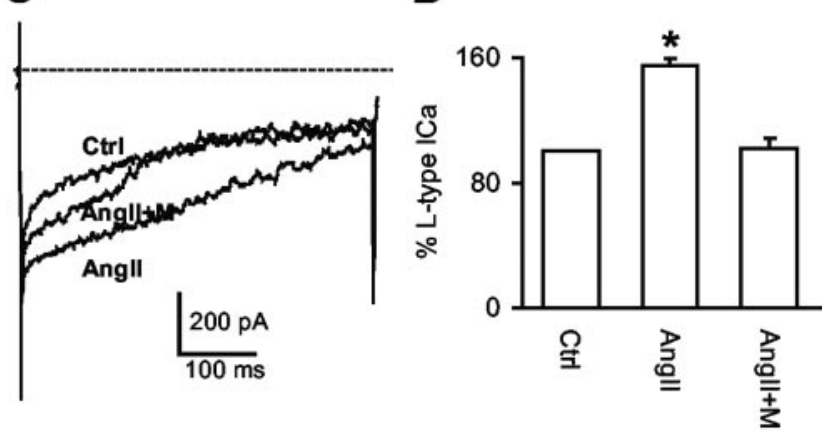

$\mathbf{E}$

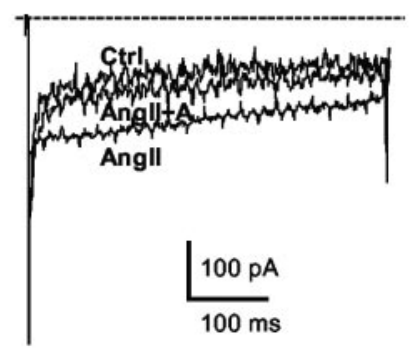

$\mathbf{F}$

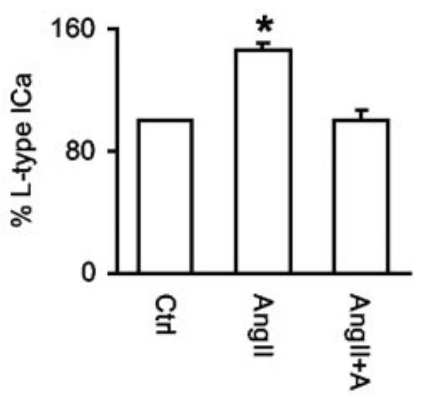

Figure 5. Angll potentiates $\mathrm{L}$-type $\mathrm{Ca}^{2+}$ currents via $\mathrm{AT}_{1}$ receptors and ROS. A, Representative traces of the $\mathrm{Ca}^{2+}$ currents from a labeled NTS neuron in control (Ctrl) conditions, with Angll $(2 \mu \mathrm{M})$, or Angll $(2 \mu \mathrm{M})$ plus losartan (L) $(2 \mu \mathrm{M})$. B, Percentage of changes in the amplitude of $\mathrm{L}$-type $\mathrm{Ca}^{2+}$ currents under the experimental conditions described in the $A(n=4)$. C, Representative traces of the $\mathrm{Ca}^{2+}$ currents from a labeled NTS neuron in control (Ctrl) conditions, with Angll ( $2 \mu \mathrm{M})$, or Angll $(2 \mu \mathrm{M})$ plus MnTBAP (M) $(30 \mu \mathrm{M})$. D, Percentage of changes in the amplitude of $\mathrm{L}$-type $\mathrm{Ca}^{2+}$ currents under the experimental conditions described in $C(n=$ 4). $E$, Representative traces of the $\mathrm{Ca}^{2+}$ currents in a labeled NTS neuron in control (Ctrl) conditions, with Angll $(2 \mu \mathrm{M})$ or Angll $(2 \mu \mathrm{M})$ plus apocynin $(A)(1 \mathrm{mM})$. F, Percentage of changes of the amplitude of $\mathrm{L}$-type $\mathrm{Ca}^{2+}$ currents under the experimental conditions described in $E(n=4) .{ }^{*} p<0.05$. The dashed line indicates zero level of the current. $\mathrm{HP}=-60 \mathrm{mV}$; $\mathrm{SP}=-20 \mathrm{mV}$. Note that the voltage-gated $\mathrm{Na}^{+}$current at the beginning of the depolarizing pulse is followed by the $\mathrm{Ca}^{2+}$ currents.

dases containing other isoforms of gp $91^{\text {phox }}$. Therefore, it is likely that the number of neurons in which $\mathrm{AT}_{1}$ receptors and $\mathrm{NADPH}$ oxidase are colocalized is larger than revealed by $g \mathrm{p} 91^{\text {phox }}$ and $\mathrm{AT}_{1}$ double labeling.

The colocalization of gp $91^{\text {phox }}$ and $\mathrm{AT}_{1}$ receptors within axon terminals in the dmNTS suggests a presynaptic action of AngII in this region (Andresen and Mendelowitz, 1996). Moreover, many of the dually labeled terminals were large and formed asymmetric
A $\quad$ B

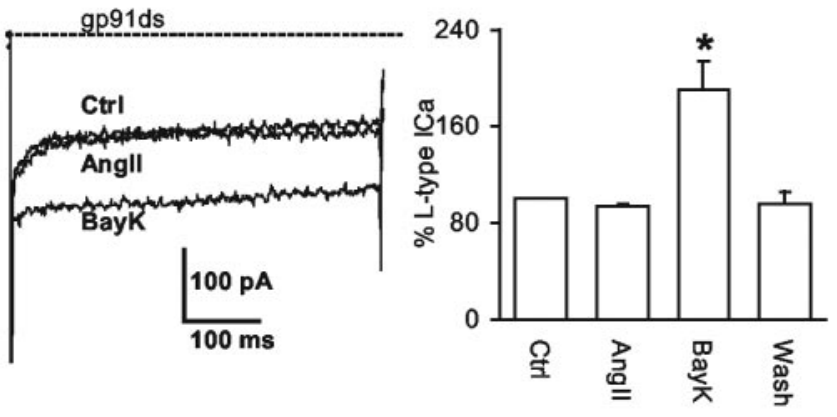

C
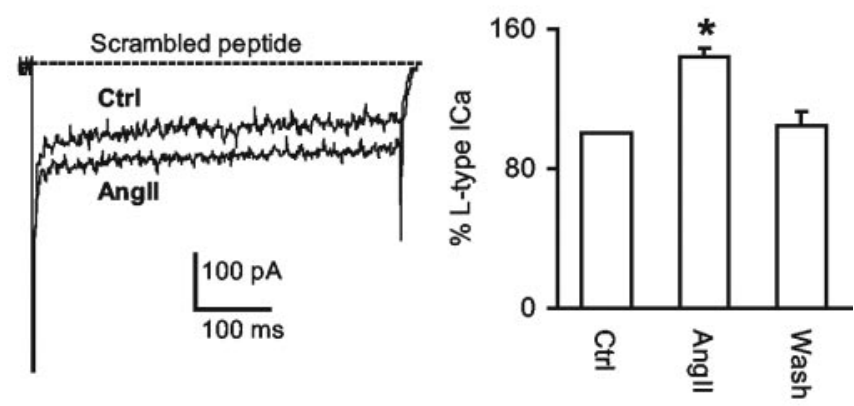

Figure 6. The peptide gp91ds blocks the Angll-mediated potentiation of L-type $\mathrm{Ca}^{2+}$ currents. $A$, Representative traces of $\mathrm{Ca}^{2+}$ currents in a labeled NTS neuron in response to Angll (2 $\mu \mathrm{m})$ or BayK $(2 \mu \mathrm{M})$ in the presence of gp91ds $(1 \mu \mathrm{M})$ in the pipette solution. $B$, Percentage of changes in the amplitude of L-type $\mathrm{Ca}^{2+}$ currents under the experimental conditions described in $A(n=4)$. C, Representative traces of $\mathrm{Ca}^{2+}$ currents in another labeled NTS neuron in response to Angll $(2 \mu \mathrm{M})$ in the presence of scrambled peptide $(1 \mu \mathrm{M})$ in the pipette solution. $D$, Percentage of changes in the amplitude of L-type $\mathrm{Ca}^{2+}$ currents in the NTS neurons under the experimental conditions described in $C(n=4) .{ }^{*} p<0.05$. The dashed line indicates zero level of the current. $\mathrm{HP}=-60 \mathrm{mV} ; \mathrm{SP}=-20 \mathrm{mV}$. Note that the voltage-gated $\mathrm{Na}{ }^{+}$current at the beginning of the depolarizing pulse is followed by the $\mathrm{Ca}^{2+}$ currents.

synapses on one or more dendrites. These features are comparable with those of vagal afferents identified by anterograde transport and are among those using glutamate as a primary neurotransmitter (Torrealba and Müller, 1996; Aicher et al., 2000). Together, these observations along with the somatodendric labeling strongly support the concept that the effect of endogenous AngII in the dmNTS involves both presynaptic and postsynaptic mechanisms (Diz et al., 2002).

The dendritic profiles postsynaptic to terminals containing gp91 ${ }^{\text {phox }}$ and $\mathrm{AT}_{1}$ receptors were often without detectable immunoreactivity, suggesting that they are not among those neurons with activity that is affected by ROS generated by NADPH oxidase activated through $\mathrm{AT}_{1}$ receptors. The dually labeled dendrites did receive, however, synaptic input from the vagal-like afferents. This is consistent with our electrophysiological evidence that not all second-order sensory neurons use an $\mathrm{AT}_{1}$ receptor-mediated, NADPH oxidase-generated ROS signaling pathway. Interestingly, some of the dually labeled dendrites in our study received convergent inputs from vagal-like afferents and inhibitory-type terminals (Torrealba and Müller, 1999) also containing both gp91 ${ }^{\text {phox }}$ and $\mathrm{AT}_{1}$ receptors. These results provide anatomical evidence that NADPH oxidase may play an important role in the presynaptic actions of AngII both in the release of glutamate from vagal afferents and in the release of inhibitory amino acid transmitters from axon terminals onto at least two 
populations of second-order sensory neurons, only one of which is postsynaptically responsive to AngII.

\section{Contribution of NADPH oxidase-derived ROS to AngII- elicited $\mathrm{Ca}^{2+}$ currents}

Our electrophysiological results are consistent with ultrastructural evidence for the coexistence of NADPH oxidase and $\mathrm{AT}_{1}$ receptors in dmNTS neurons, including those receptive to vagallike afferents, because it shows that ROS scavenger MnTBAP, the $\mathrm{p} 47^{\text {phox }}$ translocation inhibitor apocynin, and the peptide gp $91 \mathrm{ds}$ block the AngII-mediated potentiation of $\mathrm{Ca}^{2+}$ currents in identified NTS neurons. To our knowledge, these observations provide the first ultrastructural and functional evidence that NADPH oxidase-derived ROS are significantly involved in the AngII-mediated potentiation of $\mathrm{Ca}^{2+}$ currents in second-order sensory neurons. These observations also strengthen the hypothesis that NADPH-derived ROS are signaling molecules in central autonomic neurons (Zimmerman and Davisson, 2004).

The effects of AngII on cell signaling and ionic homeostasis have been documented extensively in many cell types (Berry et al., 2001). In neurons, one of the better characterized pathways involves activation of phospholipase $\mathrm{C}$ through $\mathrm{AT}_{1}$ receptors, followed by hydrolysis of phosphoinositide and increased $\mathrm{Ca}^{2+}$ release from intracellular stores (Sumners et al., 2002). The increase in $\mathrm{Ca}^{2+}$ then leads to activation of a wide variety of pathways that mediate the short- and long-term effects of AngII (Berry et al., 2001). One of these pathways, relevant to the present discussion, involves activation of NADPH oxidase through protein kinase C (Hink et al., 2001). The present results suggest that NADPH oxidase-generated ROS in response to activation of $\mathrm{AT}_{1}$ receptors activate, probably directly, the L-type $\mathrm{Ca}^{2+}$ channel. Such potentiation of $\mathrm{Ca}^{2+}$ currents provides an explanation for the finding that AngII increases neuronal excitability and spontaneous activity in some neuronal types (Ferguson et al., 2001). Thus, as in other brain regions (Wang et al., 1997; Zhu et al., 1997; Sumners and Gelband, 1998; Washburn and Ferguson, 2001), the excitatory actions of AngII in NTS neurons are caused, at least in part, by activation of L-type $\mathrm{Ca}^{2+}$ channels.

\section{Mechanisms of ROS actions on $\mathrm{Ca}^{2+}$ currents}

The AngII-mediated potentiation of L-type $\mathrm{Ca}^{2+}$ currents is characterized by negative voltage dependence, i.e., AngIIinduced ROS enhance $\mathrm{Ca}^{2+}$ currents only in response to depolarization at negative voltage steps. This finding is consistent with the report that ROS, especially superoxide, enhance $\mathrm{Ca}^{2+}$ currents only at negative depolarizing voltages (Li et al., 1998; Annunziato et al., 2002); however, the mechanisms by which ROS alter $\mathrm{Ca}^{2+}$ channel activities remain poorly understood (Kourie, 1998). One possibility is that ROS produce oxidation of sulfhydryl groups of cystine residues, resulting in the formation of disulfide bonds (S-S) that modify the structure-function relationship of $\mathrm{Ca}^{2+}$ channel proteins (Chiamvimonvat et al., 1995; Kourie, 1998; Li et al., 1998). Another possibility is that ROS lead to peroxidation of membrane phospholipids, altering the structure of the channel proteins and their ionic conductance (Kourie, 1998). A third possibility is that superoxide reacts with nitric oxide (NO) to produce peroxynitrite, which nitrates tyrosine residues in channel proteins, thereby increasing L-type $\mathrm{Ca}^{2+}$ channel activity (Ohkuma et al., 2001). Indeed, there is evidence that NO synthase (NOS) is present in NTS (Ruggiero et al., 1996) and that inhibition of NOS produces alterations in baroreceptor function induced by AngII (Paton et al., 2001; Zucker et al., 2004). This conclusion was reached on the basis of studies using dominant-negative inhibitors of endothelial nitric oxide synthase (eNOS), which blocked the effects of AngII on baroreceptors in rat heart-brainstem preparations (Wong et al., 2002). The mechanisms of this effect are complex (Ahem et al., 2002) and may also include NO-induced GABA release from NTS inhibitory neurons (Waki et al., 2003).

\section{Conclusions}

We have provided evidence that NADPH oxidase-derived ROS are responsible for the increase in $\mathrm{Ca}^{2+}$ currents evoked by AngII in second-order sensory neurons of the dmNTS. Both gp $91^{\text {phox }}$ and $\mathrm{AT}_{1}$ receptors are colocalized in these neurons, providing the ultrastructural basis for local ROS production by AngII. Although the findings have major implications for understanding the potent actions of AngII on central autonomic regulation, they support the concept that NADPH oxidase-derived ROS are critical signaling molecules in central autonomic neurons.

\section{References}

Ahem GP, Klyachko VA, Jackson MB (2002) cGMP and S-nitrosylation: two routes for modulation of neuronal excitability by NO. Trends Neurosci 25:510-517.

Aicher SA, Goldberg A, Sharma S, Pickel VM (2000) $\mu$-Opioid receptors are present in vagal afferents and their dendritic targets in the medial nucleus tractus solitarius. J Comp Neurol 422:181-190.

Andresen MC, Mendelowitz D (1996) Sensory afferent neurotransmission in caudal nucleus tractus solitarius-common denominators. Chem Senses 21:387-395.

Annunziato L, Pannaccione A, Cataldi M, Secondo A, Castaldo P, Di Renzo G, Taglialatela M (2002) Modulation of ion channels by reactive oxygen and nitrogen species: a pathophysiological role in brain aging? Neurobiol Aging 23:819-834.

Balkowiec A, Kunze DL, Katz DM (2000) Brain-derived neurotrophic factor acutely inhibits AMPA-mediated currents in developing sensory relay neurons. J Neurosci 20:1904-1911.

Batinic-Haberle I, Benov L, Spasojevic I, Fridovich I (1998) The ortho effect makes manganese (III) meso-tetrakis( $N$-methylpyridinium-2yl)porphyrin a powerful and potentially useful superoxide dismutase mimic. J Biol Chem 273:24521-24528.

Berry C, Touyz R, Dominiczak AF, Webb RC, Johns DG (2001) Angiotensin receptors: signaling, vascular pathophysiology, and interactions with ceramide. Am J Physiol Heart Circ Physiol 281:H2337-2365.

Boscan P, Pickering AE, Paton JF (2002) The nucleus of the solitary tract: an integrating station for nociceptive and cardiorespiratory afferents. Exp Physiol 87:259-266.

Cai H, Griendling KK, Harrison DG (2003) The vascular NAD(P)H oxidases as therapeutic targets in cardiovascular diseases. Trends Pharmacol Sci 24:471-478.

Chapleau MW, Abboud FM (2001) Neurocardiovascular regulation: from molecules to man. Introduction. Ann NY Acad Sci 940:13-22.

Chiamvimonvat N, O’Rourke B, Kamp TJ, Kallen RG, Hofmann F, Flockerzi V, Marban E (1995) Functional consequences of sulfhydryl modification in the pore-forming subunits of cardiovascular $\mathrm{Ca}^{2+}$ and $\mathrm{Na}^{+}$channels. Circ Res 76:325-334.

Dampney RA (1994) Functional organization of central pathways regulating the cardiovascular system. Physiol Rev 74:323-364.

Deuchars J, Li YW, Kasparov S, Paton JFR (2000) Morphological and electrophysiological properties of neurons in the dorsal vagal complex of the rat activated by arterial baroreceptors. J Comp Neurol 417:233-249.

DiBona GF, Jones SY (2003) Endogenous angiotensin affects responses to stimulation of baroreceptor afferent nerves. J Hypertens 21:1539-1546.

Dickinson CJ (1991) Neurogenic hypertension. London: Chapman and Hall Medical.

Diz DI, Jessup JA, Westwood BM, Bosch SM, Vinsant S, Gallengher PE, Averill DB (2002) Angiotensin peptides as neurotransmitters/neuromodulators in the dorsomedial medulla. Clin Exp Pharmacol Physiol 29:473-482.

Ehlers MD (2000) Reinsertion or degradation of AMPA receptors determined by activity-dependent endocytic sorting. Neuron 28:511-525.

Ferguson AV, Washburn DL, Latchford KJ (2001) Hormonal and neuro- 
transmitter roles for angiotensin in the regulation of central autonomic function. Exp Biol Med 226:85-96.

Fox AP, Nowycky MC, Tsien RW (1987) Kinetic and pharmacological properties distinguishing three types of calcium currents in chick sensory neurons. J Physiol (Lond) 394:149-172.

Griendling KK, Minieri CA, Ollerenshaw JD, Alexander RW (1994) Angiotensin II stimulates NADH and NADPH oxidase activity in cultured vascular smooth muscle cells. Circ Res 74:1141-1148.

Groemping Y, Lapouge K, Smerdon SJ, Rittinger K (2003) Molecular basis of phosphorylation-induced activation of the NADPH oxidase. Cell 113:343-355.

Hamill OP, Marty A, Neher E, Sakmann B, Sigworth FJ (1981) Improved patch-clamp techniques for high-resolution current recording from cells and cell-free membrane patches. Pflügers Arch 391:85-100.

Hink U, Li H, Mollnau H, Oelze M, Matheis E, Hartmann M, Skatchkov M, Thaiss F, Stahl RA, Warnholtz A, Meinertz T, Griendling K, Harrison DG, Forstermann U, Munzel T (2001) Mechanisms underlying endothelial dysfunction in diabetes mellitus. Circ Res 88:E14-22.

Huang J, Hara Y, Anrather J, Speth RC, Iadecola C, Pickel VM (2003) Angiotensin II subtype $1 \mathrm{~A}\left(\mathrm{AT}_{1 \mathrm{~A}}\right)$ receptors in the rat sensory vagal complex: subcellular localization and association with endogenous angiotensin. Neuroscience 122:21-36.

Ishibashi H, Akaike N (1995) Norepinephrine modulates high voltageactivated calcium channels in freshly dissociated rat nucleus tractus solitarii neurons. Neuroscience 68:1139-1146.

Kasparov S, Paton JFR (1999) Differential effects of angiotensin II in the nucleus tractus solitarii of the rat-plausible neuronal mechanisms. J Phyisol (Lond) 521:227-238.

Kim S, Iwao H (2001) Molecular and cellular mechanisms of angiotensin II-mediated cardiovascular and renal diseases. Pharmacol Rev 52:11-34.

Kourie JI (1998) Interaction of reactive oxygen species with ion transport mechanisms. Am J Physiol 44:C1-C24.

Lassègue B, Clempus RE (2003) Vascular NAD(P)H oxidase specific features, expression, and regulation. Am J Physiol 285:R277-R297.

Leranth C, Pickel VM (1989) Electron microscopic pre-embedding double immunostaining methods. In: Neuroanatomical tract-tracing methods 2: recent progress (Heimer L, Zaborszky L, eds), pp 129-172. New York: Plenum.

Li A, Segui J, Heinemann SH, Hoshi T (1998) Oxidation regulates cloned neuronal voltage-dependent $\mathrm{Ca}^{2+}$ channels expressed in Xenopus oocytes. J Neurosci 18:6740-6747.

Li JM, Shah AM (2002) Intracellular localization and pre-assembly of the NADPH oxidase complex in cultured endothelial cells. J Biol Chem 277:19952-19960.

Lohmeier TE, Lohmeier JR, Warren S, May PJ, Cunningham JT (2002) Sustained activation of the central baroreceptor pathway in angiotensin hypertension. Hypertension 39:550-556.

Mendelowitz D, Yang M, Andresen MC, Kunze DL (1992) Localization and retention in vitro of fluorescently labeled aortic baroreceptor terminals on neurons from the nucleus tractus solitarius. Brain Res 581:339-343.

Mohazzab KM, Kaminski PM, Wolin MS (1994) NADH oxidoreductase is a major source of superoxide anion in bovine coronary artery endothelium. Am J Physiol 266:H2568-H2572.

Noh KM, Koh JY (2000) Induction and activation by zinc of NADPH oxidase in cultured cortical neurons and astrocytes. J Neurosci 20:RC111(1-5).

Nowycky MC, Fox AP, Tsien RW (1985) Three types of neuronal calcium channels with different calcium agonist sensitivity. Nature 316:440-448.

Ohkuma S, Katsura M, Higo A, Shirotani K, Hara A, Tarumi C, Ohgi T (2001) Peroxynitrite affects $\mathrm{Ca}^{2+}$ influx through voltage-dependent calcium channels. J Neurochem 76:341-350.

Patel M, Day BJ (1999) Metalloporphyrin class of therapeutic catalytic antioxidants. Trends Pharmacol Sci 20:359-364.

Paton JF, Deuchars J, Ahmad Z, Wong LF, Murphy D, Kasparov S (2001) Adenoviral vector demonstrates that angiotensin II-induced depression of the cardiac baroreflex is mediated by endothelial nitric oxide synthase in the nucleus tractus solitarii of the rat. J Physiol (Lond) 531:445-458.

Paton JFR, Kasparov S (1999) Differential effects of angiotensin II on cardiorespiratory reflexes mediated by nucleus tractus solitarii-a microinjection study in the rat. J Physiol (Lond) 521:213-225.

Paxinos G, Watson C (1998) The rat brain in stereotaxic coordinates, Ed 4. New York: Academic.
Peters A, Palay SL, Webster HD (1991) The Fine structure of the nervous system. New York: Oxford UP.

Phillips MI, Sumners C (1998) Angiotensin II in central nervous system physiology. Regul Peptides 78:1-11.

Reis DJ (1984) The brain and hypertension: reflections on 35 years of inquiry into the neurobiology of the circulation. Circulation 70:11131-11145.

Rey FE, Cifuentes ME, Kiarash A, Quinn MT, Pagano PJ (2001) Novel competitive inhibitor of $\mathrm{NAD}(\mathrm{P}) \mathrm{H}$ oxidase assembly attenuates vascular $\mathrm{O}_{2}{ }^{-}$ and systolic blood pressure in mice. Circ Res 89:408-414.

Ruggiero DA, Mtui EP, Otake K, Anwar M (1996) Central and primary visceral afferents to nucleus tractus solitarii may generate nitric oxide as a membrane-permeant neuronal messenger. J Comp Neurol 364:51-67.

Sumners C, Gelband CH (1998) Neuronal ion channel signaling pathways: modulation by angiotensin II. Cell Signal 10:303-311.

Sumners C, Fleegal MA, Zhu M (2002) Angiotensin $\mathrm{AT}_{1}$ receptor signaling pathways in neurons. Clin Exp Pharmacol Physiol 29:483-490.

Suzuki Y, Wang W, Vu TH, Raffin TA (1992) Effect of NADPH oxidase inhibition on endothelial cell ELAM-1 mRNA expression. Biochem Biophys Res Commun 184:1339-1343.

Tammariello SP, Quinn MT, Estus S (2000) NADPH oxidase contributes directly to oxidative stress and apoptosis in nerve growth factor-deprived sympathetic neurons. J Neurosci 20:RC53(1-5).

Taniyama Y, Griendling KK (2003) Reactive oxygen species in the vasculature: molecular and cellular mechanisms. Hypertension 42:1075-1081.

Touyz RM, Schiffrin EL (2000) Signal transduction mechanisms mediating the physiological and pathophysiological actions of angiotensin II in vascular smooth muscle cells. Pharmacol Rev 52:639-672.

Torrealba F, Müller C (1996) Glutamate immunoreactivity of insular cortex afferents to the nucleus tractus solitarius in the rat: a quantitative electron microscopic study. Neuroscience 71:77-87.

Torrealba F, Müller C (1999) Ultrastructure of glutamate and GABA immunoreactive axon terminals of the rat nucleus tractus solitarius, with a note on infralimbic cortex afferents. Brain Res 820:20-30.

Tsien RW, Lipscombe D, Madison DV, Bley KR, Fox AP (1988) Multiple types of neuronal calcium channels and their selective modulation. Trends Neurosci 11:431-438.

Veerasingham SJ, Raizada MK (2003) Brain renin-angiotensin system dysfunction in hypertension: recent advances and perspectives. Br J Pharmacol 139:191-202.

Waki H, Kasparov S, Wong LF, Murphy D, Shimizu T, Paton JF (2003) Chronic inhibition of endothelial nitric oxide synthase activity in nucleus tractus solitarii enhances baroreceptor reflex in conscious rats. J Physiol (Lond) 546:233-242.

Wang D, Gelband CH, Sumners C, Posner P (1997) Mechanisms underlying the chronotropic effect of angiotensin II on cultured neurons from rat hypothalamus and brain stem. J Neurophysiol 78:1013-1019.

Wang G, Dayanithi G, Custer EE, Lemos JR (2002a) Adenosine inhibition via $\mathrm{A}_{1}$ receptor of $\mathrm{N}$-type $\mathrm{Ca}^{2+}$ current and peptide release from isolated neurohypophysial terminals of the rat. J Physiol (Lond) 540:791-802.

Wang G, Gorbatyuk OS, Dayanithi G, Ouyang W, Wang J, Milner TA, Regunathan S, Reis DJ (2002b) Evidence for endogenous agmatine in hypothalamo-neurohypophysial tract and its modulation on vasopressin release and $\mathrm{Ca}^{2+}$ channels. Brain Res 932:25-36.

Washburn DLS, Ferguson AV (2001) Selective potentiation of N-type calcium channels by angiotensin II in rat subfornical organ neurons. J Physiol (Lond) 536:667-675.

Wong LF, Polson JW, Murphy D, Paton JFR, Kasparov S (2002) Genetic and pharmacological dissection of pathways involved in the angiotensin IImediated depression of baroreflex function. FASEB J 16:1595-1601.

Yamaoka K, Kameyama M (2003) Regulation of L-type $\mathrm{Ca}^{2+}$ channels in the heart: overview of recent advances. Mol Cell Biochem 253:3-13.

Zhu M, Neubig RR, Wade SM, Posner P, Gelband CH, Sumners C (1997) Modulation of $\mathrm{K}^{+}$and $\mathrm{Ca}^{2+}$ currents in cultured neurons by an angiotensin II type 1a receptor peptide. Am J Physiol 273:C1040-C1048.

Zimmerman MC, Davisson RL (2004) Redox signaling in central neural regulation of cardiovascular function. Prog Biophys Mol Biol 84:125-149.

Zucker IH, Schultz HD, Li YF, Wang Y, Wang W, Patel KP (2004) The origin of sympathetic outflow in heart failure: the roles of angiotensin II and nitric oxide. Prog Biophys Mol Biol 84:217-232. 